\title{
大阪大学基礎工学部における PBL科目
}

Problem Based Learning in School of Engineering Science, Osaka University

$\begin{array}{cll}\text { 佐藤 宏 介*1 } & \text { 小坂田 宏 三*1 } & \text { 久保井 亮 一 }{ }^{* 1} \\ \text { Kosuke SATO } & \text { Kozo KOSAKADA } & \text { Ryoichi KUBOI }\end{array}$

Problem Based Leaning in School of Engineering Science, Osaka University is being achieved mainly focusing on the spontaneous setting of the project theme. The PBL program aims to promote students' wide variety of abilities ; communication skill, group discussion, presentation skill, mutual assessment of the students, and also especially research skill 3P (Plan-Perform-Publish).

Keywords : Problem Based Learning, Faculty Development

キーワード : 創造教育科目, 問題設定解決型学習, ファカルティデベロップメント

\section{1.はじめに}

近年我が国の社会体制は急激に成熟化し，若年層に おける学問への動機が失われつつある。そのような状 況の中で, 我が国が今後とも創造性と活力のある社会 を維持し，国際社会において主要な役割を果していく ためには，優れた人材の育成や新しい知恵の創造に努 めることが不可欠であり，学部教育が果すべき役割は 極めて重要となってきている，学問，研究は外から強 制されて推進する性質のものではないし，教授の仕方 や履修の仕組みを指定することで進展するものでもな いものと思われる。自主的・自発的な内省と透徹した 洞察に基づく内部からの自己研鑽によって初めて到達 きるものであり，そのような青雲の志を有する能動的 な学生を固定的な修学体系の杜に埋没させるのではな く, 適切なる活躍の場が必要といえる.

このような状況の中で基礎工学部では, 専門科目の 積極的かつ自律的な学習の動機づけを行うために, 学 部学生が自主的に立案し計画を立て, 自らの創意工夫 で進めることによって正規の単位が得られる科目「基 礎工PBL」を平成 12 年度より開講している。そこで は, 学生諸君に以下のような自律的な取り組みを求め, 教官団も積極的にその実行を支援する.

本稿では, 基礎工学部での創造教育への取り組みと して, 学部教育の中で実施している「基礎工 PBL」 科目について説明する.

\section{2. 科目創設の経緯}

大阪大学基礎工学部および大学院基礎工学研究科 は, 独立国立大学法人の中で唯一, 大阪大学にのみ設 置されている学部・研究科として, 昭和 36 年, 基礎

平成 18 年 3 月 9 日受付

$※ 1$ 大阪大学大学院基礎工学研究科
工学部は工学部や理学部の朹を越え,「科学と技術の 融合による科学技術の根本的な開発, それにより人類 の真の文化を創造する学部」という理念のもとに設立 された，そのため, 自然と人間の調和, 次世代の科学 技術の開拓に向け, 時代の要請に応じて, 制御工学科, 生物工学科, 情報工学科などの新しい学科を新設して きた。

8 大学工学部長懇談会において実施が決まった創成 型科目について, 学部内で約 1 年間, その具体化を検 討した。平成 12 年度については科目配当が既に済ん でいたため，科目の読替えや実施時期などを変えて変 則的に行い, 平成 13 年度から本格的に実施すること になった。

基礎工学部は工学部と理学部との中間的な学部とし て設置されたため, 幅広い 10 種のコースがあり, 毎年 約 480 名の学生が入学する。 そのため, 創成型科目を 「デザイン型科目」として，すべてのコースで同一内容 で一斉実施することは現実的ではないと考えられた。 そ こで, 創成型科目を「各コースを修了した学生が当面す るであろう問題を単純化，モデル化したような問題を解 決することを体験させることにより，そのコースで学ぶ 科目の必要性, 得るべき能力について自覚させる」よう な科目である，と設計した，そのためPBLの呼称には， Project Based Learning, Product Based Learningなど があるが, Problem Based Learning とした.

創成型科目を実施する意義については, 以下のよう な当初, 幅広い意見があった。

(1) 米国の産業が即戦力的なデザイン力を重視して いるのに対し, 日本の産業は, 工学の基礎を確実 に収得した学生の方が望まれている.

（2）日本の大学の入学生は, 工学を学ぶ目的意識が 薄く, これに対する対応の方が重要である.

（3）デザイン型科目とすると, 工学的な色彩の薄い 
表 1 創造教育科目と他科目との接続

\begin{tabular}{|c|c|c|c|c|}
\hline 学年 & 種別 & 名 称 & 担 当 & 内 容 \\
\hline \multirow{2}{*}{ e } & 導入 & 基礎セミナー & 実践センター & $\begin{array}{l}\text { 大学での学習への } \\
\text { 入門教育 }\end{array}$ \\
\hline & 導入 & ～科学序説 & 基礎工学部 & 学科への入門教育 \\
\hline 2 & 創造 & 基礎工PBL & 基礎工学部 & $\begin{array}{l}\text { コースに関わる導 } \\
\text { 入型創造教育 }\end{array}$ \\
\hline 3 & 専門 & ～論 & 基礎工学部 & $\begin{array}{l}\text { コースに関わる専 } \\
\text { 門教育 }\end{array}$ \\
\hline 4 & 専門 & 特別研究 & 基礎工学部 & $\begin{array}{l}\text { コースに関わる包 } \\
\text { 括型創造教育 }\end{array}$ \\
\hline
\end{tabular}

コースでは該当しなくなる.

（4）基礎工学部では 2 年進級時でコース分けするた め, 2 年生でコースの学習内容を理解させるよう な科目が必要である。

そこで, 表 1 に示すように, 大阪大学実践センター 提供の導入科目である「基礎セミナー」, 基礎工学部 が提供する「〜科学序説」という学科と 2 年次から分 属するコースの紹介科目を開講している. 大阪大学で は，共通教育と呼ばれる，昔の教養部と似た教育が最 初の 3 セメスターの間に実施され， 1 年生の間には各 種の教養教育, 専門基礎教育のほか, 情報処理教育な ど少ない専門科目が配置されている. これらの基礎教 育は, 大学科（それぞれ，2～ 3 の専門コース, 従来 の定員 40 ～80名の小学科からなる）単位で行われ， 2 年次進級時に専門コースに別れて配属されることか ら，PBL科目は 2 年次に配当することとした。たた し，コースの専門分野に差異が少ない, 情報科学科の 計算機科学コースとソフトウェア科学コースが 1 年次 で開講している。

\section{3. 様々な基礎工PBL}

表 2 に示すように，コースそれぞれの専門分野に配 慮し, 科目内容は各コース毎に設定している。そのた
め, 以下のような幅広いバリエーションが生じた. こ れは機械科学のような物作りに則したコースから，数 理科学コースのような抽象的な議論を行うコースまで 幅広く諸科学分野をカバーしているため, その内容に 強い拘束を与えなかったからである.

科目名称には，独自の名称，あるいは基礎工 $\mathrm{PBL}$ にコースの名称を組み合わせたものにした。

開講時期 : 1 年次, 2 年次前期, 2 年次後期 必修選択の別：必修科目，選択科目

テーマの与え方：メニュー選択制，自主設定，教員 との協議（ミニ卒論）

学生の構成 : 個人別, グループ別

グループディスカッション：あり，なし

プレゼンテーション：あり，なし

レポート提出：あり，なし

評価法: 教員評価, 学生自己評価, 学生間相互評価 学生表彰：あり，なし

\section{4. コース別基礎工PBL}

\section{1 エレクトロニクスコース}

テーマは 10 数個. 下記にその例をいくつか示す. これらの中から 2 テーマを選び， 6 週程度かけて 1 つ のテーマに取り組む（ 2 人 4 人゙ 1 班を構成し, 協力 して当たる），最後に成果報告（プレゼンテーション） とデイスカッション，ディベートを行う。その他，小 グループでのコミュニケーションとプロジェクト立案 のスキルを学ぶ.

・コイン選別システムの設計試作：自動販売機など に利用されるコイン選別, おつりなどのシステム の設計, 試作する.

・静止衛星打上げプログラムの製作 : 静止衛星の打 ち上げから軌道に乗せるためのプログラムを作成 し，さらにその様子を $\mathrm{CG}$ で表現する.

・ソーラーカーおもちゃを設計, 試作し, レースを 行う. ソーラーセルは最大個数が決まっている.

表 2 基礎工学部各コースで実施されている創成科目の一覧

\begin{tabular}{|c|c|c|c|c|c|c|}
\hline コース & 学期 & 指定 & テーマの与え方 & 学生構成 & プレゼン & レポート \\
\hline エレクトロニクス「基礎工PBL」 & 2 年後期 & 必修 & 6テーマから 2つをメニュー選択 & グループ $(2-4$ 人 $)$ & $\bigcirc$ & $\bigcirc$ \\
\hline 物性物理科学「基礎工PBL」 & 2 年後期 & 選択 & 13テーマから 1つをメニュー選択 & 個 & $\bigcirc$ & - \\
\hline 合成化学「化学研究入門」 & 2 年前期 & 選択 & 10テーマから 1つをメニュー選択 & $\begin{array}{l}\text { 個人（グループを設 } \\
\text { 定する場合もある） }\end{array}$ & $\bigcirc$ & - \\
\hline 化学工学「基礎工PBL」 & 2 年後期 & 必修 & 自主設定 & グループ & $\bigcirc$ & $\bigcirc$ \\
\hline 機械科学「機械科学セミナー」 & 2 年前期 & 選択 & 自主設定 & グループ & $\bigcirc$ & $\bigcirc$ \\
\hline 電子システム学「基礎工PBL」 & 2 年前期 & 選択 & 自主設定 & $\begin{array}{l}\text { 個人（グループを設 } \\
\text { 定する場合もある） }\end{array}$ & $\bigcirc$ & - \\
\hline 生物工学「基礎工PBL」 & 2 年後期 & 選択 & 自主設定 & 個 & - & O \\
\hline $\begin{array}{l}\text { 計算機科学・ソフトウェア } \\
\text { 科学「情報工学 A」 }\end{array}$ & 2 年前期 & 必修 & 自主設定 & グループ & $\bigcirc$ & O \\
\hline $\begin{array}{l}\text { 計算機科学・ソフトウェア } \\
\text { 科学「情報工学 B」 }\end{array}$ & 2 年後期 & 必修 & 自主設定 & グループ & $\bigcirc$ & $\bigcirc$ \\
\hline 数理科学「基礎工PBL」 & 2 年前期 & 必修 & 指定 2 テーマ & 個 & - & O \\
\hline
\end{tabular}


重さは問わず，速度を競う。

・創作折り紙：鶴のような簡単なものではなく，蟹 や烏賊のように手足の多い難しい折り紙や，フラ ーレン（C60），サッカーボールなど複雑な構造 の折り紙に挑戦, 数学以上に頭を使う。立体感覚 を養い，感性を磨く。

- 基本的かつ実用的な電子回路の設計, 製作 : オペ アンプを利用した定電圧電源, トランジスタ増幅 回路（低周波, 高周波), フィードバック制御回 路（定值，追值）などの回路を自ら調べて設計し, 組み立て, 調整を行い動作させる.

・空中イルミネーションー何もないはずの空間に, 様々な文字や図形，アニメーションを表示する。

方法, 原理や仕組等, 自由な発想で実現させる.

成績評価は, 出席, 学習態度, 成果, プレゼンテー ション, ディスカッション, ディベート, レポートな どを通じ総合的に評価する.

\section{2 物性物理科学コース}

まず, PBL科目についての説明とテーマの選択に 1 週を要し, 10〜 12 週で以下のテーマの中から一つ を選び自主的に研究活動を行う（平成16年度の例）. 最後の 1 週で研究活動を行って得た成果を他の人に分 かりやすく説明すると同時に，他の人の成果発表を聞 いて内容に関する議論を行う。成果発表から成績評価 する.

·磁石と超伝導

・色素増感型太陽電池の製作と特性

・超伝導・超流動を見てみよう

・ブラウン運動

・計算機で物質の高圧状態を調べる

・半導体で作るガスセンサ

・ナノカーボン材料の物性を探る〜ナノチュー ブ・フラーレンを中心にして〜

・光のアート・光の諸性質を測る

・パーコレーション物理現象をシミュレーションし よう

- 光通信

・真空を測る

・面白炭素工（考）房－御花炭からダイアモンドま で-

\section{3 合成化学コース}

有機化学, 無機化学, 物理化学, および高分子化学 各分野の教員が設定するテーマについて, その背景, 目的などを講義したあと，受講生各自がそれに基づい て自ら学習, 調查, 実験計画の立案, 提案を行い, 可 能ならば研究室での実験実習などを教員の個別指導の もとに行う.これを通して, 化学研究を行う上で求め られる英語論文を読む力, 文献調査, テーマに関連し た実験手法, 実験データの処理, 調查・研究のプレゼ ンテーション等について学ぶ．各年度のテーマは履修
指導の際, 提示するが, 提示するテーマは 10 種類程 度を予定しており, 受講人数に応じてグループを設定 する場合がある。成績評価は，レポート，発表及び出 席.

\section{4 化学工学コース}

学外コーディネータとして, 三菱電機島田彌氏を招 聘し, 科目内容と教育実践の指導を受けている。講義 内容は, 学生自身が興味を持っている物質生産・環 境・エネルギー分野・その他の身近な問題から解決し たい課題を自主設定させる. その課題に対して少人数 グループ討議を行って解決の可能性を探り, その結果 をレポートにまとめ発表させ, 化学工学コースの各教 科の勉学の動機づけを行う。主旨説明から始まり, コ ミュニケーションリテラシー\&スキル講義・演習, 問 題探索のグループ討議と結果の発表, 図書館やインタ 一ネットを利用した情報検索と収集, 問題解決を目指 したグループ討議と進渉状況報告, 学内学外講師によ る講義, 研究室見学, レポート作成とポスター発表. 企業の専門家（島田氏）による指導も含め, グループ ディスカッション, 進渉状況報告, ポスター発表など 通常の授業とは全く異なる授業となる. 少人数教育に より学生と教員との間の密なコミュニケーションが可 能で, 自立した学生を目指して積極的に参加すること を目指す。成績評価は出席, プレゼンテーション, レ ポート, 面接で行う。

平成 16 年度のテーマ例は,「人体により優しいへア カラーを提案する」,「新しい太陽光発電を提案する」, 「ペットボトル凍結時の安全性を考える」,「プラスチ ック代替物を提案する」,「最善の洗髪方法を考える (第 7 回学生発表会西日本地区にて発表)」,「太陽電池 を利用する新しい発電システムを提案する」，「折りた たみ可能なペットボトルを提案する」,「光触媒を消臭 に利用する」である。

\section{5 機械科学コース}

機械科学 (非線形力学, 機械情報, 宇宙機械, 生体 機械）の中で, 最近の話題などを提示し，それらの中 で学生が興味を持ち，原理や構造を知りたい，あるい は疑問点を解決したいと思うテーマを，自主的に設定 させる，たとえば，H 2 ロケット，カーナビ，ハイブ リッド自動車, 人間型ロボット, リモート手術, 人工 臓器, 高機能材料など. 教員側の実施手順は以下のと おりであり, 成績評価を出席, テーマへの取り組み, レポート,プレゼンテーション等により総合的に評価 する. 図 1 に授業風景を示す。

1）テーマ毎に受講者を数人のグループに分ける.

2) プロジェクト計画を企画させる.

3）各グループに担当教員を置く.

4) 問題解決にむけての取り組み方を指導する。（問 題と目標の設定, 調查方法の例示, 学生の役割分担, インターネットの利用，図書検索など） 


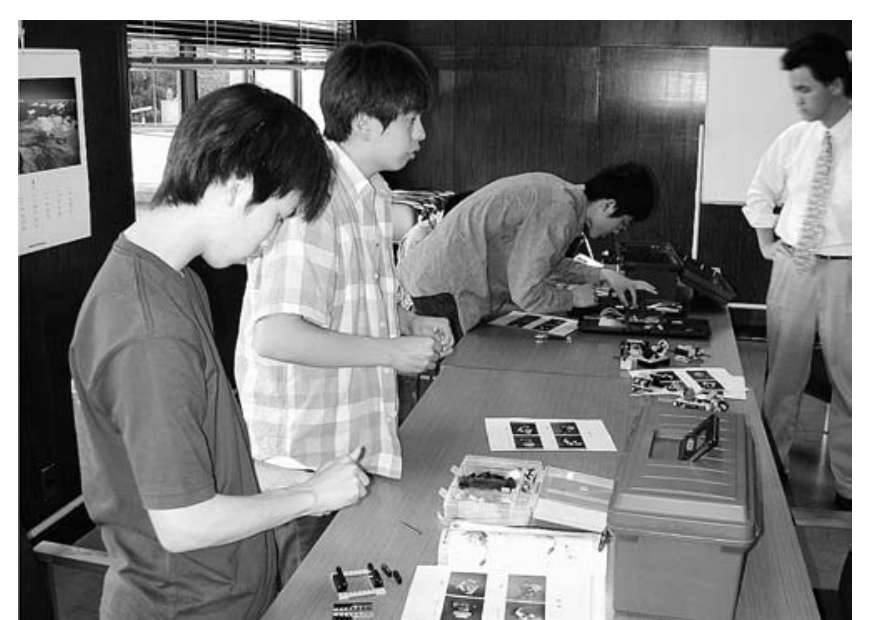

図 1 機械科学セミナー（機械科学コース）授業風景

5 ) 進渉状況を報告書にまとめさせる(レポート指導). ポスター, OHPなどによるグループ内中間発表.

6 ）全グループのポスターによるプレゼンテーション （展示，ショートプレゼンテーション，院生など含 めた質疑）

\section{6 電子システム学コース}

具体的テーマについて, 講義, 演習, 調査, 実験, 解析，設計，発表などを適宜組み合わせた問題解決型 の内容とする．具体的には，まず初めに，各教員が提 示するテーマを参考にし, 自身の興味に基づいて学生 が自ら取り組む研究課題を決定し，その研究計画をま とめて教員に提出する. その研究計画書に基づいて, 学科の全教員の中から適任者が担当指導教員として選 ばれる，学生は，担当指導教員のアドバイスを受けな がらテーマを主体的に進め, 最後に他の学生や教員に 対してプレゼンテーションを行う. 割当教員との相談 により実施期間は決定されるが，夏季に集中実施する ことが多い。また学生自らが派遣先企業を獲得できる ならば，企業実習，企業インターンについても，本科 目において単位を認める。ただしその場合も, プレゼ ンテーションを行う必要がある。成績評価は, テーマ に対する取り組み, 成果発表プレゼンテーションなど

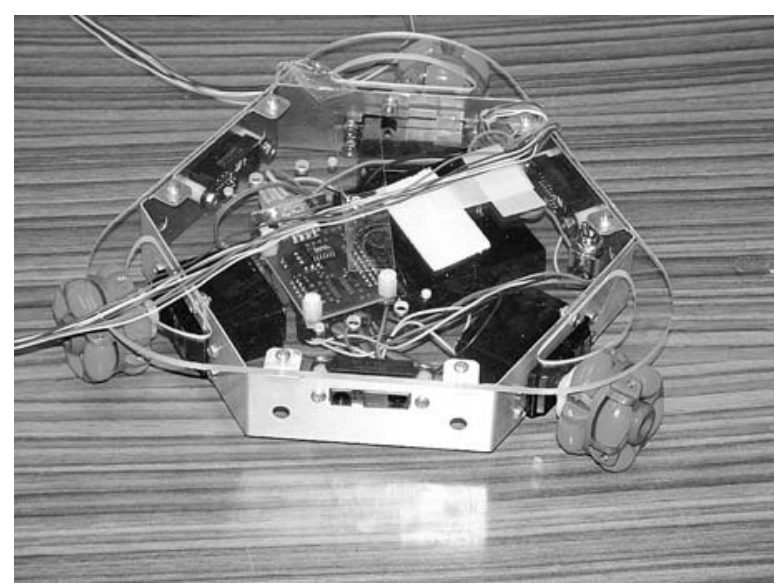

図 2 電子システム学「基礎工PBL」(電子システム学コー ス）で学生が自主制作したロボット
を総合的に評価する．図 2 に学生が自主制作した制作 物を, 図 3 に優秀賞の受賞や発表会の様子を公開して いるPBLのホームページを示す。

教員は指導, 支援を行うが, 学生が自らの創意工夫 で進めることが肝要のようである. ホームページを介 して連絡するので, インターネット環境に頻繁に接し させ，ホームページで公開している過去の実施状況を 参考にさせる.

\section{7 生物工学コース}

与えられた講義内容ではなく, 自主的に少人数チー ムとして問題・課題そのものとそれらの解決法を見つ けだしていく能力を養うための実験・演習である. 生 物工学分野の全てのテーマを対象とする. 教科書的な 問題設定や解法例だけではなく, さまざまな別のアプ ローチがないかを考えて見ることは, 科学の本質に通 じる. 指導教員は課題の選択と適宜助言を与えるコン サルタントの役割を果たすが, この講義ではあくまで も脇役である。事前に自分が興味を持つ領域・テーマ に関係がありそうな教員に相談し, その指導教員とコ 一ス主任の許可を得て行う。成績評価は, 演習の状況, 終了時にレポート提出によって総合的に判断する.

4. 8 計算機科学・ソフトウェア科学コース

全員に対し実施の仕方や方法について説明し, 通常 は配属された研究室に行き, そこで教員や院生と接触 し, 課題についてチーム学習する. 報告や発表なども 行う. 成績評価は, 成果物についての評価, 授業への 出席, 貢献度についての学生同士の相互評価などを総 合する、質問・相談等はメールおよび授業支援システ ム（コンピュータセンター, 図書館, 情報処理教育セ ンターが一体化した大阪大学独自の組織であるサイバ ーメディアセンターが, 全学に提供しているWebCT コースウェアなど）にて随時受け付ける. 自ら進んで 積極的に取り組んでいくことが必要である，1年次後 期では主に議論の仕方, レポートの書き方・発表の仕 方を体得させ, 高校までの学習スタイルからまず脱却 させる. その後, 2 年次で特定のテーマに取り組ませ,

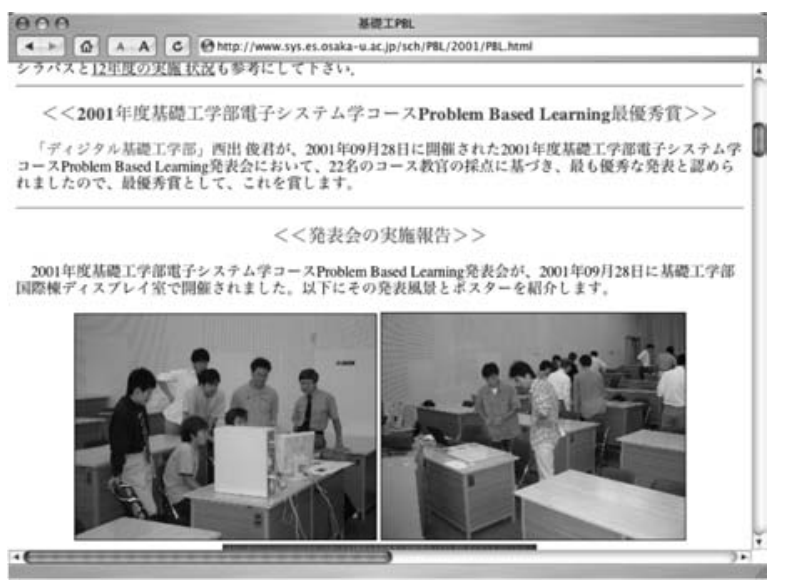

図 3 電子システム学「基礎工 PBL」基礎工 PBL（電子シ ステム学コース) のホームページ 
大学における学習スタイルに馴染ませる. 以下にその 課題例をいくつか挙げる.

・対戦ゲームのアルゴリズム設計とプログラム作成 および実地評価

・初心者のための情報技術講座の設計

・仕様策定を含むプログラム設計と作成

・情報分野の先端技術やシステム実現事例の調查

\section{9 数理科学コース}

まず, 高校数学や大学 1 年生で学んだ数学を Mathematica などの数式処理ソフトウェアを用いて再現さ せる. プログラミングとグラフィックスを通じて数学 を視覚的にとらえさせる．次に，新聞・雑誌などにあ ふれるデー夕をExcelやStatisticaなどの統計ソフト ウェアによって解析させる，パソコンと統計ソフトゥ エアを用いてデー夕解析し, 今何が起こっているかを デー夕に語らせる，成績評価は，積極的な取り組みの 様子や提出されたレポート提出による.

\section{5.おわりに}

創造教育科目の評判は受講生の間では非常に良い. 化学工学コースで実施した自己・相互評価に対するア ンケート調査の分析では，コミュニケーションリテラ シー\&スキルの講義，ならびに，小グループ討論での 学生による自主的な課題設定から, 自分自身のテーマ についてよく考えているようである2).さらに自己評 価・相互評価を実施することにより，全体としては， 1 ) 学生の間に適度な緊張感が得られるばかりでなく, 個人レベルでは 2 ）他人の中の（他人と比較した）自 分を見直すきっかけとなり，3）他人に指摘された盲 点, あるいは自分自身が認識した欠点を自律的な動機 付けにリンクさせて考える学生の育成に繋がっている 様子も窥える。

PBL科目を履修した学生はその後の専門課程にお ける講義・学生実験において, 従来の学生とは異なる 印象を持つ, との意見も一部の教員から聞かれる。例 えば, 学生実験等では, 実験に対する意欲も高い, 意 見（建設的な意見あるいは異論）を堂々と述べる，な どの意見も聞かれている。学生の自律的な動機付け . 活性化の一助となっているものとも考えられ, 少なく とも学生が潜在的にもつ意識を喚起する役割は果たし ていると考えられる.

また，これら PBL科目は一人の教員が担当するの ではなく、コースの教員団が担当する（多くのコース ではコース全教員が分担する）ため，科目内容の設 計・更新, アンケート調查の分析の協議すること自体 が，教員団のファカルティデベロップメントにつなが
っていることは大変良い副作用である.

前述のように受講生側の評判は極めて良い。優秀な 活動に対して表彰を行うコースもあり，学生のよい動 機付けに役立ってる. しかしながら, 逆に教員側の評 判はそれほどよくない，例えば，この数年間での実施 において,

1) 受講生数に比較して, 投入しなくてはならない教 員数が多い

2）教員毎にも多大な負担がかかる

3 ）演習に必要な資材購入費の手当て

4）公正公平な評価

5 ）グループ演習に適した教室（大セミナー室, 小セ ミナー室等）がない

6 ）選択科目の場合に, 負担を気にする学生が多く, 受講者数が想定ほど多くない,

というような問題点が教員の多くより指摘されてお り, いずれも容易に解決できない点を含んでいるから である，特に，独法化により管理業務が膨れ上がって いる旧国立大学の教員にとって, 一般科目, 学生指導 深刻である，解決すべき問題は山積しているが, 創造 教育科目を通じて一人でも多く「元気な」学生を輩出 していきたいと基礎工学部では考えている.

\section{参 考 文 献}

$1 ）$ 電子システム学コース「基礎工 PBL」ホームペ ージ, http://www.sys.es.osaka-u.ac.jp/sch/ PBL/2005/index.html

2）久保井亮一, 島田 彌, 江頭靖幸, 海老谷幸喜, 紀 八岡正博, 高橋英明, 佐藤 博, 馬越 大, 白石康 浩, 芝 定孝：テーマの自主設定に特に注力した 化学工学系 2 回生への PBL教育とその効果, 工学 教育, $53-4,18-22$ (2005)

\section{著 者紹介}

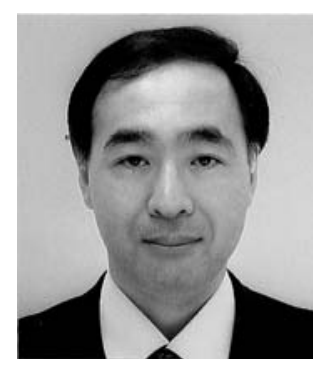

佐藤 宏介

大阪大学大学院基礎工学研究科 システム創成専攻システム科学領域 教授（基礎工学部教務委員長）

1983 年 3 月大阪大学基礎工学部制御工学科 卒, 1985 年 3 月同大学院基礎工学研究科修 士課程修了, 1986 年大阪大学基礎工学部助 手, $1988-90$ 年カーネギメロン大学ロボッ 卜工学研究所客員研究員, 1994年奈良先端 科学技術大学院大学情報科学研究科助教授, 2003 年大阪大学大学院基礎工学研究科教授, 現在に至る 